\title{
The Integration of Games in Teaching English as a Foreign Language in the Classroom: Moulay Ismail University as a Case Study
}

\section{BEN EL MOUDDEN Mossaab}

Moulay Ismail University

benmossab5@gmail.com

\section{Dol:https://doi.org/10.36892/ijlls.v3i1.425}

\begin{tabular}{|c|c|}
\hline $\begin{array}{l}\text { Received: } \\
\text { 11/01/2021 }\end{array}$ & $\begin{array}{l}\text { Abstract } \\
\text { This paper puts emphasis on the integration of games in the teaching of English }\end{array}$ \\
\hline $\begin{array}{l}\text { Accepted: } \\
15 / 03 / 2021\end{array}$ & $\begin{array}{l}\text { as a foreign language, with the aim of investigating the impacts of using games } \\
\text { in the classroom on the process of learning English as a foreign language, the } \\
\text { students'perception towards the use of games, the students' skills, their } \\
\text { participation in games, and their attitudes. The research approach adopted is }\end{array}$ \\
\hline $\begin{array}{l}\text { Keywords: } \\
\text { Games, Teaching, } \\
\text { English, Foreign } \\
\text { Language, } \\
\text { Classroom }\end{array}$ & $\begin{array}{l}\text { the quantitative approach. The tool used to collect quantitative data is a } \\
\text { questionnaire. The questionnaire was administered to one group of foreign } \\
\text { language students, who study at the university of Letters and Human Sciences } \\
\text { in Moulay Ismail University in Meknes, Morocco. The sample includes fifty } \\
\text { male and female participants. The findings show that the integration of games } \\
\text { in the classroom helps the foreign language students to improve their four } \\
\text { language learning skills, vocabulary repertoire, critical thinking skills, problem } \\
\text { solving skills, team work skills and encourages them to participate in the } \\
\text { classroom. Furthermore, the findings indicate that the use of games in the } \\
\text { classroom has many positive impacts on the perceptions of students towards the } \\
\text { technique of game-based teaching, their attitudes towards the language, the } \\
\text { teacher, and themselves. The significance of the study lies in raising the } \\
\text { teachers' awareness of the importance of the integration of games in teaching } \\
\text { English as a foreign language. }\end{array}$ \\
\hline
\end{tabular}

\section{INTRODUCTION}

The learning of a language is not merely a serious process devoid of the elements of fun and playing as it has been thought about for many centuries. In fact, the elements of fun and playing make the language more powerful than it is as Rooyackers( 2002: Preface) points out "Language is immensely powerful, but it can also be loads of fun. In fact, a sense of fun can make language more powerful ..... Language and play complement and enrich each other." One teaching technique that is characterized by the elements of fun and play is the use of games which is very fruitful and beneficial in both language teaching and learning. This paper is about the implementation of games in teaching English as a foreign language in the classroom. The paper will bring to the fore the advantages of using games in the classroom and shed light on some challenges to take into consideration while using games, which have not been dealt with in other studies of literature. This will add to the previous body of literature and fill in some gaps. The paper also aims to investigate the impact of using games in the classroom on the Moroccan English foreign language students in the Moroccan context in terms of learning 
English as a foreign language, the academic performance of students, their attitudes, and other important skills.

\subsection{Statement of the Problem}

The problematic issue that guides the needs of conducting this study is to determine whether the integration of games in the classroom has a positive impact on the learning of English as a foreign language. The case study in this paper will be of great help to educators, researchers, and teachers since it will make them better understand the effects of using games on the learning of English as a foreign language.

\subsection{Objectives of the Study}

The research objectives are as follow:

To contribute to the existing, previous body of literature with regard to the use of games in teaching English as a foreign language.

To investigate the impact of games-based teaching on learning English as a foreign language, To find out if the game-based teaching improves the language learning skills of students.

To raise teachers' awareness of the impact of using games in teaching English as a foreign language.

To generate some recommendations related to the topic under investigation.

\subsection{Questions of the Study}

This study is conducted with the purpose of answering the following research questions:

1- To what extent do students learn English as a foreign language through games-based teaching?

2- Does games-based teaching help learners to practice their English?

3- Does game-based teaching create an appropriate environment for students to learn English as a foreign language?

4- To what extent are students satisfied with games-based teaching?

\section{Theoretical Background}

\subsection{Definition of Game}

A game has been defined differently from different perspectives. Some definitions of games do not fall within the framework of learning English as a foreign language. In this respect, I will try to shed light on some definitions of games in relation to language learning. To start with, Jassim and Dzakiria (2019) define a game as "an educational technique related to learning."(p:49). Simply put, this means that games can be used as a teaching technique for the sake of learning. Conversely, Blanka (2015) points out that a "game is a natural means for children to understand the world around them. Therefore, it should be part and parcel of their learning, including the learning of foreign languages."'(p.1157). Blanka's definition indicates that games provide learners, especially children with the appropriate environment in which they can use their senses in one way or another to have an idea about the world. Children discover and learn many things, such as interacting with their peers or teachers, learning names of new objects, using body language, touching each other, having fun, and so on... . For Blanka, games are of great value to children and learners in general since they create a good atmosphere that is a necessary prerequisite forunderstanding the world and learning foreign languages.

In line with Blanka's definition Haldfield (1999) points out that "a game is an activity with rules, a goal and an element of fun... Games should be regarded as an integral part of the language syllabus, not as an amusing activity for Friday afternoon or for the end of the 
term.'(pp:102-104). This means that games are characterized by rules that must be respected, an aim which guides the needs of playing it, and the aspect of fun that stimulates learning. To clarify the definition more, before the teacher wants to create a game or present it to the learners in the classroom, he sets rules of playing the game that the learners should follow so as to know how to play the game as well as to avoid problems in terms of the classroom management during the game playing process. This clearly shows that a game is an organized activity.

On the other side of the coin, El Shamy (2001) defines a game as a "competitive activity played according to rules within a given context, where players meet a challenge to achieve an objective and win". (P.15). This simply means that games involve competition and challenges that are the driving forces behind the achievement of a goal. The challenge might be a problem supposed to be solved by students, questions to answer, and so on.... The ones who figure it out or find answers tothe questions etc... are the winners. This definition is closely related to the approach of competitive learning in which language learners challenge each other in a specific setting for the sake of reaching a goal. The definition also indicates that games can be played in different settings. Similarly, Dorn (1989) defines a game as "any contest or play among adversaries or players operating under constraints or rules for an objective goal". (p. 2).

\subsection{Categories of Games}

Games have various categories and types. They are different language games that can be divided based on many goals and characteristics. Hadfiled (1998) gives two main categorizations of language games. She divides them into linguistic and communicative ones. With respect to the linguistic games, they are accuracy oriented. Differently put, the main focus is on the correctness of structures of sentences, pronunciation of words, the use of tenses, spellings etc... . The teacher uses linguistic games to enhance the accuracy of students and correct their mistakes in the usage of the English language. On the other hand, communicative games are fluency oriented. The aim is to exchange information successfully. The teacher uses these games to boost the communicative skills and help them to convey their thoughts, opinions etc... without giving too much attention to their mistakes in terms of grammar, pronunciation, sentence structure, and so on and so forth.

They are many language games used for different learning levels, such as beginners, intermediates, advanced learners etc.... The list of games types that can be used in the classroom for the sake of teaching English as a foreign language is really long and changeable, such as, vocabulary games, number games, structure games, spelling games, conversation games, writing games, grammar games, role-play, dramatics, business and management games, instructionalgames, etc... . Hadfiled, (1998), (Cited in Blanka 2015, pp:1158) introduces a list of games that has linguistics and communicative features as follow:

- Sorting games (ordering or arranging games). In these games, students are given a set of cards with different names of objects on them, and the students have to arrange them into two lists. For instance, students have a set of cards with different names of old and new means of transportation, and they have to sort them into the means of transportation used in the past and now.

- Information gap games. In such games, one or more students have information the other students need to complete a task. For instance, one person might have a drawing and their partner needs to create a similar drawing by listening to the information given by the person with the drawing

- Guessing games. These are a variation on information gap games. One of the best-known examples of a guessing game is 20 questions, in which one person thinks of a well-known 
person, place, or thing. The other participants can ask 20 yes/no questions to find clues in order to guess who or what the person is thinking of.

- Search games. These games are yet another variant oftwo-way information gap games, with everyone giving and seeking information. For example, students are given information about a well-known person and try to find his or her name. Students can also be given a grid. The task is to fill in all the cells in the grid with the name of a classmate who fits that cell, for example, someone who is a vegetarian. Students circulate, asking and answering questions to complete their grid and help classmates complete theirs.

- Matching games. As the name implies, participants need to find a match for a word, picture, labels, card etc... . For example, students place 30 word cards, composed of 15 pairs, face down in random order. Each person turns over two cards at a time, with the aim of turning over a matching pair, by using their memory.

- Labelling games. These are a form of matching, in that participants match labels and pictures.

- Exchanging games. In these games, students barter cards, other objects, or ideas.

- Board games. Scrabble is one of the most popular board games that specifically highlights language.

- Roleplay games/dramas. Roleplay can involve students playing roles that they do not play in real life, such as dentist, while simulations can involve students performing roles that they already play in real life or might be likely to play, such as customer at a restaurant. Dramas are normally scripted performances, whereas in role-plays and simulations, students come up with their own words, although preparation is often useful.

Csikszentmihalyi (1990) (cited in Robert, 2005 p. 36 ) discussed from a psychological perspective how Roger Caillois (1958/2001), classified games into four main classes based on the types of experiences they provide to the players. The first type is agnostic games. They are mainly characterized by the feature of competition that is the cornerstone upon which agnostic games are based. These types of games push the player to use their skills to compete with each other so as to develop mind sets of challenges. For example, the teacher gives two groups of students the beginning of a story and asks them to write its end. When the students finish writing their story, one student from each group has to stand and tell it in front of other students by using body language, intonations, and so on. The group of students who write and tell the best story wins. Students use their linguistics and communicative skills to come up with the best story.

The second type is the aleatory games. The element of chance is the main feature in these games. These games give the players the illusion that they somehow have power over the games results. The third type is vertigo or ilinix games that change the consciousness of the players by scrambling ordinary perceptions. The last type of games is the mimicry games which give the players the possibility of creating other realities such as theatre, role-playing, and arts in general. These games affect the feelings of the players in a way that they feel as if they are more than they actually are through imagination, fantasy, pretence, and disguise. Caillois (1958/2001) uses the term simulation as a synonym for mimicry.

In line with Roger Caillois classification, the "Folk Model" (cited in Robert,2005) divides games into four non-exclusive categories that are games of skill, games of chance, games of strategy, and simulation games (Wikipedia, 2005). Games of skill include board games, card games, letter games, mathematical games, puzzle games, guessing games, word games, games of physical skill, and instructional games. With respect to games of chance, they 
include dice games, card games, casino games, lottery-type games, Bingo, and Pifiata. Concerning games of strategy, they are checkers, Chess, Go, and Mastermind. Last but not least, simulation games include role-playing games, board games like Monopoly, and computer and video games. Indeed, games have a lot of categories.

\subsection{Advantages of Games}

It is no more a secret that using games have a lot of advantages. Learners learn best a language when they receive a pleasant, interesting input as Krashen (2011) argues in his compelling input hypothesis that learners acquire the language in a better way and improve in it when they receive an input that is interesting to them. He also points out the fact that when learners receive compelling input, they acquire the language whether they are interested in improving in it or not. To put it simply, compelling input makes learners acquire the language unconsciously. The implementation of games in language learning is one of the ways that provide compelling input to the learners and promote language learning unconsciously.

To begin with, games encourage students to cooperate with each other and learn in teams. According to Franklin, Peat \& Lewis (2003), when students work cooperatively on a gaming activity, "games foster group cooperation and typically create a high level of student involvement that makes them useful tools for effective teaching" (p. 82). In this realm, when the students play games in teams, it enhances their team work skills and cognitive abilities in the sense that games create a stress- free environment that is the driving force of effective teaching and foreign language learning. This is what is known as the cooperative learning gaming methods that play a vital role in teams work since they help the learners develop their cooperative learning skills and prepare them psychologically for the learning process.

Not only do the cooperative learning gaming methods encourage students to learn in teams and develop their learning skills, but they also help students to achieve their academic goals successfully and develop positive attitudes towards the subject matters. This is what is proven in the study of Ke and Grabowski (2007) who conducted a study in which one hundred twenty-five fifth graders participated in a cooperative Team-Games Tournament. The TGT has three basic elements. Students are assigned to "three-member teams randomized on equivalent achievement levels whose membership remains intact throughout the cooperative learning process". The games consist of skill exercises that are played in tournaments on aweekly basis. Students compete individually against other students and their winnings are brought back to their teams. They found that the cooperative learning game technique used in the tournament improves students' academic achievement and attitudes towards the subject matter.

Odenweller, (1998) cited in Mubaslat, (2012) points out that games boost students' involvement, motivation, and interest in the material or the subject taught and allow the instructor to be creative and original when he presents topics. (p:8). This simply means that games lead the students to love the subject taught and give the possibilities for the teacher to use imagination, creativity, and originality when presenting topics. To clarify more, the teacher can create his or her new games that suit the goals of each topic. For example, if the teacher wants to present a topic that is about jobs and wants teach the names of jobs in English, he can use the game of role acting in which some students do certain jobs by acting, and the others are supposed to say the exact name in English of the job acted. 
Another advantage of using games is that they lower the stress level and anxiety of students which is very important in learning a language. The learning process of English as a foreign language requires confidence, relaxation, and positive attitudes towards the foreign language, the teacher, and the students themselves. Learners who have low level of anxiety and stress are more likely to succeed in learning a language compare to students who have a high level of stress. This is what Krashen(2013) argues in his affective filter hypothesis. Krashen claims that students who have a high filter acquire the language and progress in it in comparison with the other students with low filter. Krashen means that if is anxious, has low self-esteem, and does not consider himself to be a member of a group that speaks the language, he or she will not certainly acquire the language and progress in it.

The implementation of games can encourage students to participate. If the teacher wants the students to participate in the classroom and use the language, he should encourage and motivate them to take an active part in different activities. One way to achieve these goals is to use game-based learning as (Schultz \& Fisher, 1988) (Cited in Vijayalakshmi,2014) rightly states "games can stimulate and encourage students to participate in the activity since naturally, they want to beat the other teams... Apart from having fun, students learn at the same time. They acquire a new language. Students begin to realize that they have to use the language if they want others to understand what they are saying".(p:3). Gozcu and Caganaga (2016) conducted a study on two undergraduate students who were taught English by using the game called 'Twister'. The researchers used multi-method triangulation; semi-structured interviews and observation which add to the credibility of the research. The findings reveal that the game provides a positive atmosphere for EFL, motivates them, and results in high learning performance. However, this study has a methodological limitation which is the sample of the study. The sample is not representative since two respondents are not enough to come to a reliable, scientific conclusion.

Games do motivate learners to learn a foreign language. One reason is that many games promote competition. According to Nalasco (1991) "in addition to the personal challenge, younger students also enjoy competing with their peers, and introducing a game element is a way of livening up any material"'( p.76). Nevertheless, I should highlight the point that the element of competition is double-edged. Previous body of literature and studies in the implementation of games in the process of learning English as a foreign language have not given importance to the socio-cultural background of learners related to the element of competition in games. Competitive games, specifically the ones based on competition between individual learners can be fruitful if it is used in individualistic societies that give great value to competition between individuals, such as the U.S.A, Switzerland etc... . However, if this kind of games are used in collectivistic societies, such as China, Japan, South Korea etc..., it might not be beneficial in terms of language learning. This is because in collectivistic societies, people appreciate more working in groups than competing individually. language learners who are from collectivistic societies feel at ease when they work in groups and compete against other groups. Nevertheless, they become uncomfortable when they compete individually against each other. This might hinder the effective learning of a language. In this regard, the socio-cultural background of learners should be taken into consideration before deciding which game to use, and how to use it.

Games encourage shy learners to participate in the classroom as Hansen (1994) states, "Games are highly motivating and entertaining, and they can give shy learners more opportunity to express their opinions and feelings." (p:118). Nevertheless, it is not more often the rule than the exception. It is necessary to take into consideration the fact that there are some 
introvertedstudents who do not like to participate in the classroom not because they are shy or cannot participate, but because it is a trait of their personality. Games based learning might not be of great help to introvert English Foreign language learners. To this end, the teacher should carefully select a game that suits these types of learners. For instance, the teacher can use a game in which introvert learners feel comfortable such as by giving random words and ask them to combine sentences by using the same words. Then, the teacher will observe them and reward them when they combine correct sentences without asking them to stand and say the sentence in the front of their classmates.

A lot of surveys have proved the effectiveness of games in the learning of foreign languages. (cf. Carrier, 1985; Chen, 2005; Jacobs, n.d. b; or Kupeckova, 2010). Games basedlearning have a lot of advantages, specifically in the learning of a foreign language Blanka (2015) gives the following advantages of games based-learning and its impact on the process of learning a foreign language:

- Games get students involved in their learning; they motivate them.

- Games encourage creative and spontaneous use of language (cf. Chen, 2005).

- Games introduce a change in formal learning situations.

- Games create a pleasant stress-free and relaxing atmosphere in a language class.

- Games unconsciously promote and practise all four basic language skills, such as listening, reading, speaking and writing.

- Games help the teacher to create contexts in which the language is useful and meaningful. (cf. Wright, Betteridge, \& Buckby, 2005).

- Games decrease student's anxiety to speak in front of the other students; they feel less intimidated in this, less formal learning situation.

- Games are student-centred.

- Games can promote collaboration among students.

- Games can connect to a variety of intelligences. (Gardner, 1999, as cited in Jacobs, n.d. b).

Games have the feature of flexibility. They can be played online. Games -based learning can take place in many virtual communities and platforms. In this day and age, a lot of teachers all over the world use distance learning as a way of teaching their students instead of classroom teaching due to the outbreak of Corona virus that is very contagious. Teachers create virtual groups or use some digital platforms, such as Facebook, WhatsApp, Zoom, Google classroom, Go to meeting and so on in which they can deliver courses and interact with their students. Though many teachers do their best to make distance learning successful, many students feel bored or stressed during the online course, especially young English foreign language learners as children because they have a short span of attention. As a result, they lose attention or become passive receivers of information. In this regard, teachers can gamify their online lessons by using many online games as computer games in order to attract the students and provide them with active opportunities of learning as Karen (2011) points out: "In the technological realm, there are many computer-based games that provide active learning opportunities and reinforce topics learned in the classroom. "'(p.11).

The computer games- based approach can be very effective in learning English as an FL. Connolly and Stansfield (2006) define it as "the use of a computer games-based approach to deliver, support, and enhance teaching, learning, assessment, and evaluation"( $p 466$ ). In 
addition to the advantages of computer-based games mentioned in Stanfield's definition, computer-based games can be used as warm-up activities in the online session so as to prepare the students for learning new vocabularies about topics, introducing them to new unites, learning grammatical rules etc... . However, when using these types of games, the teacher should take into account the organization and arrangement of the ways of playing these games in a way that can lead to beneficial interaction between students and the computer-based games or their peers as Karen (2011) indicates "one important aspect for educators to consider when employing these games is the way in which they arrange for students to interact with the computer-based game and with their peers".(p.11). First and foremost, the teachers and the students should have technological literacy. They should know how to use technological devices or online technologies in order to know how to play computer-based games and benefit from them when it comes to learning English as a foreign language. Teachers can also use digital educational games for the sake of learning English as a foreign language as Wang and Dostal ( 2018 ) clearly say "digital educational games are tools for learning English as a foreign language and they can be used as a supplement for classroom teaching."'(p: 144). They are other games that the teacher can use or create to reach some goals in learning English as a foreign language as developing the communicative skills of learners.

Games can be useful to develop the communicative skills of learners. Teachers can use communicative games for the benefit of English foreign language students whose communication skills are poor. Ratna, Ummi, and Ari (2016) Conducted a study with the aim of investigating the impact of communicative games on teaching speaking skills and the communicative skills of students in which they used the Classroom Action Research (CAR) based on Kurt. L model. The procedures followed in the research were planning, acting, observing, and reflecting. With respect to the instruments used for collecting data, they were interviews, observation, questionnaire, and test. They clearly found out that the communicative games have had a positive impact on the teaching and learning processes which indicated that communicative games enhance students' enthusiasm and motivation. Most importantly, the researchers found that communicative games improve students' active participation, confidence and fluency in speaking skills.

Games develop different types of communication skills. They develop the communication skills of public speaking, communicating in teams, convincing the others etc.... Furthermore, games can improve the four language learning skills which are listening, speaking, reading, and writing as Wright, Betteridge and Buckby (2006) ( cited in Deguang, 2012) say "games can be found to give practice in all the skills, in all the stages of the teaching and learning and for many types of communication". P.(802). In the same line, Hadfield (1990) (cited in Mania) confirms that "games provide as much concentrated practice as a traditional drill and more importantly, they provide an opportunity for real communication, albeit within artificially defined limits, and thus constitute a bridge between the classroom and the real world."(p:6). In this realm, games give the possibilities of practicing communication skills as in real-life communication.

Games are stress-free ways of learning vocabulary. Students have the opportunity of improving their vocabulary repertoire through play vocabulary games. Calvo-Ferrer (2017) investigated the game impact on vocabulary learning. In his study, he targeted two groups of participants. The first group of participants was exposed to the vocabulary of the foreign language by using games while the other group learnt the foreign language vocabulary by practicing vocabulary exercises in their textbooks. The results in pre and post-tests demonstrated that the outcomes of the participants who were taught vocabulary through games 
were better compared to those who learned vocabulary by using traditional ways. Vocabulary learning is not a matter of learning by heart; nevertheless, the learners should use vocabulary in different contexts which is very important since words can have various meanings in specific contexts.

Last but not least, games improve the skills of problem-solving. The skill of problemsolving is very demanding in the lives of students in general and in their carrier in specific. It is one of the most important skills in the $21^{\text {st }}$-century education. (Wismath, Orr \& MacKay, 2015). Problem-solving is one of the basics upon which games are based, and it makes them more interesting and challenging as MacKenty (2006) states "it's the act of problem-solving that makes games so engaging... devoid of challenge or risk of failure, games really aren't all that much fun" (p. 46). If games and their instructions are well designed, students can simultaneously build their problem-solving skills while having fun throughout the process. (MacKenty, 2006;Harris, 2009).

\section{Methodology}

The type of study adopted in this paper is the quantitative study. I also opted for the single instrumental case study. Stake (1995) states that the "researcher focuses on an issue or concern, and then selects one bounded case to illustrate this issue" (Stake, 1995 cited in Creswell, 2007: 74). The single group targeted is the Facebook group of Moulay Ismail University.

\subsection{The Study Sample}

The type of sampling adopted is convenient or non-probability sampling. The group targeted is the Facebook group of Moulay Ismail University. All of the participants are students at the University of Moulay Ismail and foreign language learners. They study in different semesters, such as S2, S5, and S6. The sample size is 50 students, and they are 25 males and 25 females.

\subsection{The Instrument of Data Collection}

The questionnaire is the data collection tool used with the aim to collect quantitative data. The questionnaire consists of four main parts, and each part has a set of questions. The first set of questions are demographic ones that include three items participants are required to determine. Participants are required to choose their "gender" by choosing male or female, their "age", in which respondents are supposed to choose one option among three options which are "18 years to 12 years old", " 22 years to 30 years old", and 30 years to 60 years old". In the last demographic question, students are required to choose "their level of education" by choosing one option among the three following options: "Semester 2", "Semester 4", "Semester 6". There is also another question asked to elicit information about the frequencies of using games in the classroom by teachers. The second set of questions is arranged from question number 5 to 11 . The questions are asked in order to elicit information about the frequencies of using games by teachers, the perceptions and feelings of students towards the use of games in teaching English as a foreign language, and their participations in games. The questions are measured on the Likert- scale in which they are four or five items from which one item is supposed to be chosen: "always", "usually", "sometimes", "never", or "strongly agree", " agree", "uncertain", "disagree", "strongly disagree", or "important", "very 
important", "less important", "unimportant". The third set of questions starts from question number 11 to 18 . The questions are used to extract information about the impact of gamesbased teaching on the learning of English as a foreign language in terms of the four language learning skills and other important skills. The questions are measured on the Likert-scale in which there are five choices from which participants are supposed to choose: "strongly agree", "agree", "uncertain", "disagree", and "strongly disagree". The fourth and the last set of questions is arranged from question number 19 to 24 . The questions are used to get information about the effect of using games on the attitudes of English foreign language learners towards each other, the language, and the teacher. The questions also aim to know the impact of gamebased teaching on the motivation of students and their emotional barriers tolanguage learning. These questions are measured on the Likert -scale in which there are five choices supposed to be chosen: "strongly agree", "agree", "uncertain", "disagree", and "strongly disagree". The questionnaire was created by (using Google Forms). It was administered online to students of Moulay Ismail University by posting it in their English Department online groups and sent privately in messages through social media

\subsection{Data Analysis}

The collected, quantitative data are measured statistically, using the software of Microsoft Excel version 2007. The collected statistics are descriptive. Descriptive statistics included frequencies, means and standard deviation. With regard to the graphical representation of data, pie charts and frequency distribution tables are used. The Cronbach's Alpha Coefficient test is used to test to make sure that all the questions and scales have the reliability.

Table 1. Reliability Statistics of the Questionnaire Items

\begin{tabular}{|c|c|}
\hline Cronbach's Alpha & N of Items \\
\hline .823 & 24 \\
\hline
\end{tabular}

The table above shows the Cronbach's Alpha (Reliability Coefficient), which is a test used to test the internal reliability and consistency of a set of scales or the questionnaire items. The Cronbach's Alpha is proven to be a reliable, credible test a researcher has to use in order to insure the reliability of the questions used before the processes of examination and distribution of any sets of questions. George and Mallery (2003) provides the following rules of thumb: "_> .9 - Excellent,_>.8-Good,_>.7- Acceptable,_> .6-Questionable,_>.5 - Poor and $<.5$ - Unacceptable" (231). The table above shows that the 24 questionnaire items are reliable, for the alpha coefficient is .82 . This means that there is a good internal consistency among the questionnaire items based on the criteria of the Cronbach' alpha test.

\section{RESULTS}

Figure 2.Distribution of participants by gender 


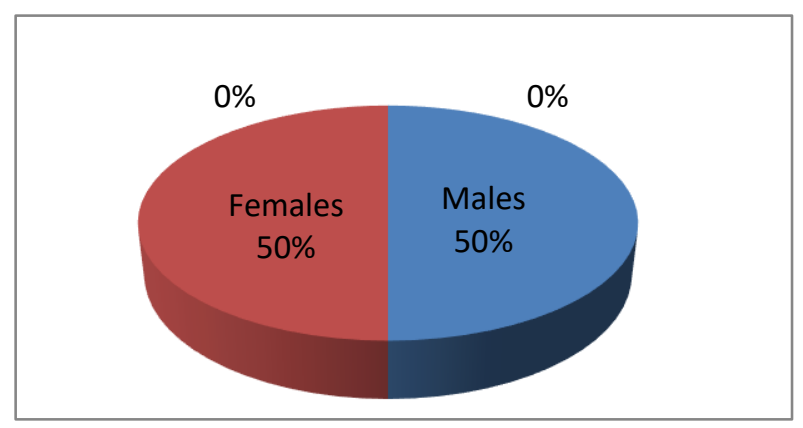

The pie chart above shows the number of participants in terms of gender distribution. As demonstrated in the pie chart, males and females are both selected in equal way; each gender represents $50 \%$ in the whole sample $(n=50)$.

Table 3.Distribution of participants by age

\begin{tabular}{|c|c|c|}
\hline Age & $\begin{array}{c}\text { Number of } \\
\text { Respondents }\end{array}$ & Percentage \\
\hline $\mathbf{1 8}$ to 22 years old & 17 & 34.0 \\
\hline $\mathbf{2 2}$ to 30 years old & 16 & 32.0 \\
\hline $\mathbf{3 0}$ to 50 years old & 17 & 34.0 \\
\hline Total & 50 & 100.0 \\
\hline
\end{tabular}

The table above shows the distribution of participants by age. The age of participants is selected equally except that there is a small difference between participants who are between 22 to 30 years old and the other participants. The participants who are 18 to 22 years old represent 24 percent of the whole population, and the participants with the age of 30 to 50 years old also represent 27 percent of the whole population while the participants who are between 22 to 30 years old represent 16 percent of the whole population.

Table 4.The participants' level of education

\begin{tabular}{|c|c|c|c|}
\hline $\begin{array}{c}\text { Level of } \\
\text { Education }\end{array}$ & Semester 2 & Semester 4 & Semester 6 \\
\hline $\begin{array}{c}\text { Number of } \\
\text { respondents }\end{array}$ & 16 & 17 & 17 \\
\hline
\end{tabular}

The table above shows the level of education of participants. As demonstrated, 16 participants study in S2, and17 participants are in S4 while 17 participants study in S6. The participants' level of education is selected almost equally in order to ensure that no group of participants is favoured over the other. There is a slight difference in the participants who 
studied in S2 compared to the other participants, which does not affect the reliability of the questionnaire.

Table 5.Responses of the Question: Do your teachers use games in the classroom?

\begin{tabular}{|c|c|c|c|}
\hline & Frequency & Percent & Valid Percent \\
\hline Always & 5 & 10.0 & 38.0 \\
\hline Usually & 3 & 6.0 & 12.0 \\
\hline Sometimes & 11 & 22.0 & 42.0 \\
\hline Rarely & 17 & 34.0 & 8.0 \\
\hline Never & 14 & 28.0 & 0.0 \\
\hline Total & 50 & 100.0 & 100.0 \\
\hline
\end{tabular}

The table above displays the frequency of using games by teachers in the classroom. A total of 5 participants, representing $10 \%$ out of $n=50$ choose the "always" option, and only 3 participants, representing $6 \%$ out of $n=50$ have ticked the "usually" option while a total of 11 participants, representing $22 \%$ choose the "sometimes" choice. A total of 17 participants, representing $34 \%$ out of $n=50$ opt for the "never" option; moreover, 14 (28\%) participants choose the "never" choice. As demonstrated above, the findings indicate that $31(62 \%)$ participants out of $n=50$, representing the majority of the whole sample choose the rarely or the never option. This means that games are rarely or never used in the classroom.

\subsection{The perceptions of students towards the use of games in teaching English as a} foreign language, and their participation in games

Table 6.Responses of the Question: Do you enjoy game-based teaching?

\begin{tabular}{|c|c|c|c|}
\hline & Frequency & Percent & Valid Percent \\
\hline Always & 20 & 40.0 & 38.0 \\
\hline Usually & 14 & 28.0 & 12.0 \\
\hline Sometimes & 8 & 16.0 & 42.0 \\
\hline Rarely & 5 & 10.0 & 8.0 \\
\hline Never & 3 & 6.0 & 0.0 \\
\hline Total & 50 & 100.0 & 100.0 \\
\hline
\end{tabular}

The table above shows how often students enjoy game-based teaching. A total of 20 respondents, representing $40 \%$ out of $n=50$ opt for the "always" option, and a total of $14(28 \%)$ participants out of $n=50$ choose the "usually" choice while $8(16 \%)$ participants out of $n=50$ select the "sometimes" option. A total of $5(10 \%)$ participants out of $n=50$ tick the "rarely" option, and only $3(6 \%)$ participants out of $n=50$ choose the "never" option. These findings demonstrate that $34(68 \%)$ participants out of $n=50$ who represent the majority of the whole sample choose either the "always" or the "usually" option. This indicates that students always or usually enjoy game based teaching.

Table 7.Responses of the Question: Do you participate in the classroom when the teacher uses games? 


\begin{tabular}{|c|c|c|c|}
\hline & Frequency & Percent & Valid Percent \\
\hline Always & 19 & 38.0 & 38.0 \\
\hline Usually & 6 & 12.0 & 12.0 \\
\hline Sometimes & 21 & 42.0 & 42.0 \\
\hline Rarely & 4 & 8.0 & 8.0 \\
\hline Never & 0 & 0.0 & 0.0 \\
\hline Total & 50 & 100.0 & 100.0 \\
\hline
\end{tabular}

The table above portrays the frequency of students' participation when teachers use games. A total of 19 (38\%) participants out of $n=50$ opt for the "always" option, and $6(12 \%)$ participants out of $n=50 \mathrm{opt}$ for the "usually" option while $21(42 \%)$ participants "sometimes" participate in the classroom when using games. For the participants who choose the "rarely" option, they are only five ( $8 \%$ ) out of $n=50$, and no participant chooses the "never" option. These findings reveal that $46(92 \%)$ participants, representing the majority of the sample choose either the "always" option or the "usually" option or the "sometimes" option. This invokes that when teachers use games in the classroom, the students do participate a lot.

Table 8. Responses of the Question: Do you feel comfortable when play games in the classroom?

\begin{tabular}{|c|c|c|c|}
\hline & Frequency & Percent & Valid Percent \\
\hline Always & 11 & 22.0 & 22.0 \\
\hline Usually & 24 & 48.0 & 48.0 \\
\hline Sometimes & 7 & 14.0 & 14.0 \\
\hline Rarely & 3 & 6.0 & 6.0 \\
\hline Never & 5 & 10.0 & 10.0 \\
\hline Total & 50 & 100.0 & 100.0 \\
\hline
\end{tabular}

The table above shows the frequencies of feeling comfortable when playing games in the classroom. According to the table, a total of 11 (22\%) participants out of $n=50$ "always" feel comfortable while playing games, and $24(48 \%)$ participants "usually" have the feeling of comfort when playing games while 7 (14\%) participants choose the "sometimes" option. Furthermore, only $3(6 \%)$ participants out of $n=50$ select the "rarely" option, and $5(10 \%)$ participants out of $n=50$ choose the "never" option. Based on the findings above, $35(70 \%)$ participants representing the majority of the sample usually or always feel comfortable when playing games in the classroom. This explains that using games in the classroom makes students feel comfortable.

Table 9. Responses of the Question: How do you perceive the use of games in the classroom?

\begin{tabular}{|c|c|c|c|}
\hline & Frequency & Percent & Valid Percent \\
\hline Important & 21 & 42.0 & 42.0 \\
\hline Very Important & 17 & 34.0 & 34.0 \\
\hline
\end{tabular}




\begin{tabular}{|c|c|c|c|}
\hline Less Important & 9 & 18.0 & 18.0 \\
\hline Unimportant & 3 & 6.0 & 6.0 \\
\hline Total & 50 & 100.0 & 100.0 \\
\hline
\end{tabular}

The table above shows the students perception of the use of games in the classroom. A total of $21(42 \%)$ participants out of $n=50$ perceive games as important, and $17(34 \%)$ participants consider games as very important while $9(18 \%)$ participants out of $n=50$ see games as less important. The participants who view games as unimportant are only $3(6 \%)$ out of $n=50$. Based on these findings, $38(76 \%)$ participants out of $n=50$, representing the majority perceive games as important or very important. This indicates that the integration of games in the classroom is very important to students.

Table 10.Responses of the Question :Do you agree that games should be used in the classroom to teach English as a foreign language?

\begin{tabular}{|c|c|c|c|}
\hline & Frequency & Percent & Valid Percent \\
\hline Strongly agree & 37 & 74.0 & 74.0 \\
\hline Agree & 9 & 18.0 & 18.0 \\
\hline Uncertain & 1 & 2.0 & 2.0 \\
\hline Disagree & 2 & 8.0 & 8.0 \\
\hline Strongly disagree & 1 & 2.0 & 2.0 \\
\hline Total & 50 & 100.0 & 100.0 \\
\hline
\end{tabular}

The table 10 deals with to what degree students agree or disagree with the idea of using games in the classroom to teach English as a foreign language. The results show that $37(74 \%)$ participants out of $n=50$ opt for the "strongly agree" option, and $9(18 \%)$ participants out of $\mathrm{n}=50$ choose the "agree" option while only 1 participant is uncertain. The participant who disagree are only $2(8 \%)$ out of $=50$, and $1(2 \%)$ participant out of $(2 \%)$ selects the "strongly disagree" option. This means that the majority of participants strongly agree with implementing games in the teaching of English as a foreign language.

4.2. The impact of games-based teaching on the learning of English as a foreign language, the skills of students, and their academic performance

Table 11. Responses of the statement: I improve my speaking skills when playing communicative games.

\begin{tabular}{|c|c|c|c|}
\hline & Frequency & Percent & Valid Percent \\
\hline Strongly agree & 25 & 50.0 & 50.0 \\
\hline Agree & 15 & 30.0 & 30.0 \\
\hline Uncertain & 7 & 14.0 & 14.0 \\
\hline Disagree & 0 & 0.0 & 0.0 \\
\hline Strongly disagree & 3 & 6.0 & 6.0 \\
\hline Total & 50 & 100.0 & 100.0 \\
\hline
\end{tabular}


The table above is about the statement "I improve my speaking skills when playing communicative games." The results show that $25(50 \%)$ participants strongly agree with the statement, and $15(30 \%)$ participants out of $n=50$ choose the "agree" option while $7(14 \%)$ out of $n=50$ are uncertain. No participant disagrees with the statement, and only $3(6 \%)$ out of $n=50$ strongly disagree with the statement. The findings indicate that $40(80 \%)$ participants out of $\mathrm{n}=50$, representing the majority of the sample strongly agree or agree with the statement. This means that the use of communicative games in the classroom improves the communicative skills of students.

Table 12 .Responses of the statement: I improve my listening skill when playing listening games.

\begin{tabular}{|c|c|c|c|}
\hline & Frequency & Percent & Valid Percent \\
\hline Strongly agree & 9 & 18.0 & 18.0 \\
\hline Agree & 35 & 70.0 & 70.0 \\
\hline Uncertain & 2 & 4.0 & 4.0 \\
\hline Disagree & 3 & 6.0 & 6.0 \\
\hline Strongly disagree & 1 & 2.0 & 2.0 \\
\hline Total & 50 & 100.0 & 100.0 \\
\hline
\end{tabular}

The table above is about the statement "I improve my listening skill when playing listening games". A total of $9(18 \%)$ participants out of $n=50$ "strongly agree" with the statement, and $35(70 \%)$ "agree" with it while only $2(4 \%)$ participants out of $=50$ are uncertain. $3(6 \%)$ participants out of $n=50$ "disagree" with the statement, and only 1 participant "strongly disagree" with it. These findings shows that the choices of "strongly agree" and "agree" outnumber the other choices which means that listening games boost the listening skills of students.

Table13.Responses of the statement: I improve my writing skills when playing writing games.

\begin{tabular}{|c|c|c|c|}
\hline & Frequency & Percent & Valid Percent \\
\hline Strongly agree & 19 & 38.0 & 38.0 \\
\hline Agree & 22 & 44.0 & 44.0 \\
\hline Uncertain & 2 & 4.0 & 4.0 \\
\hline Disagree & 4 & 8.0 & 8.0 \\
\hline Strongly disagree & 3 & 6.0 & 6.0 \\
\hline Total & 50 & 100.0 & 100.0 \\
\hline
\end{tabular}

The table above has to do with the statement "I improve my writing skills when playing writing games". A total of $19(38 \%)$ participants out of $n=50$ "strongly agree" with the statement, and 22 (44\%) participants choose the "agree" option while only 2 (4\%) participants 
out of $n=50$ are "uncertain". A total of 4 participants out of $n=50$ opt for the "disagree" option and only $3(6 \%)$ participants "strongly disagree" with the statement. The findings demonstrate that the chosen choices of "strongly agree" and "agree outdo the other choices. This reveals that playing writing games enhances the writing skills of students.

Table 14.Responses of the statement: Vocabulary games improve my vocabulary repertoire.

\begin{tabular}{|c|c|c|c|}
\hline & Frequency & Percent & Valid Percent \\
\hline Strongly agree & 27 & 54.0 & 54.0 \\
\hline Agree & 20 & 40.0 & 40.0 \\
\hline Uncertain & 0 & 0.0 & 0.0 \\
\hline Disagree & 2 & 4.0 & 4.0 \\
\hline Strongly disagree & 1 & 2.0 & 2.0 \\
\hline Total & 50 & 100.0 & 100.0 \\
\hline
\end{tabular}

For table 14, it tackles the statement "vocabulary games improve my vocabulary repertoire". The results show that a total of $27(54 \%)$ participants out of $n=50$ "strongly agree" with the statement, and a total of $20(40 \%)$ participants "agree" with the statement while no one is uncertain. 2 ( $4 \%$ ) participants out of $n=50$ "disagree" with the statement, and the "strongly disagree" option is selected only by one participant. The findings demonstrate that 47 (94\%) participants, representing the majority "strongly agree" or "agree" with the statement. This reveals that vocabulary games improve the students' vocabulary repertoire.

Table 15.Responsesto the statement: Playing games improve my problem solving skills.

\begin{tabular}{|c|c|c|c|}
\hline & Frequency & Percent & Valid Percent \\
\hline Strongly agree & 31 & 62.0 & 62.0 \\
\hline Agree & 12 & 24.0 & 24.0 \\
\hline Uncertain & 7 & 14.0 & 14.0 \\
\hline Disagree & 0 & 0.0 & 0.0 \\
\hline Strongly disagree & 0 & 0.0 & 0.0 \\
\hline Total & 50 & 100.0 & 100.0 \\
\hline
\end{tabular}

The table above is about the statement "playing games improves my problem solving skills". A total of $31(62 \%)$ participants out of $n=50$ choose the "strongly agree" option, and $12(24 \%)$ participants out of $n=50$ opt for the "agree option" while $7(14 \%)$ participants out of $\mathrm{n}=50$ are uncertain. The other options of "disagree" and "strongly disagree" are not selected at all. The findings show that $43(86 \%)$ participants out of $n=50$, representing the majority of the whole sample "strongly agree" or "disagree" with the statement. This reveals that the use of games enhances the problem solving skills of students.

Table 16 .Responses of the statement: Game-based teaching improves my academic performance.

\begin{tabular}{|c|c|c|c|}
\hline & Frequency & Percent & Valid Percent \\
\hline Strongly agree & 9 & 18 & 18 \\
\hline Agree & 22 & 44.0 & 44.0 \\
\hline
\end{tabular}




\begin{tabular}{|c|c|c|c|}
\hline Uncertain & 16 & 32.0 & 32.0 \\
\hline Disagree & 3 & 6.0 & 6.0 \\
\hline Strongly disagree & 0 & 0.0 & 0.0 \\
\hline Total & 50 & 100.0 & 100.0 \\
\hline
\end{tabular}

The table above has to do with "game-based teaching improves my academic performance". The results show that $9(18 \%)$ participants out of $n=50$ "strongly agree" with the statement, and $22(44 \%)$ participants out of $n=50$ choose the "agree" option while $16(32 \%)$ participants out of $n=50$ are uncertain. Only $3(6 \%)$ participants out of $n=50$ "disagree" with the statement, and no participant "strongly disagree" with it. The findings show that $29(62 \%)$ participants out of $n=50$, representing the majority "strongly agree" or "agree" with the statement. This indicates that game-based teaching can improve the academic performance of students.

Table17.Responses of the statement: Game-based teaching improves my critical thinking skills.

\begin{tabular}{|c|c|c|c|}
\hline & Frequency & Percent & Valid Percent \\
\hline Strongly agree & 18 & 36.0 & 36.0 \\
\hline Agree & 5 & 10.0 & 10.0 \\
\hline Uncertain & 15 & 30.0 & 30.0 \\
\hline Disagree & 4 & 8.0. & 8.0. \\
\hline Strongly disagree & 8 & 16.0 & 16.0 \\
\hline Total & 50 & 100.0 & 100.0 \\
\hline
\end{tabular}

The table above is about "game-based teaching improves my critical thinking skills". A total of $18(36 \%)$ strongly agree with the statement, and $5(10 \%)$ participants out of $n=50$ "agree" while $15(30 \%)$ participants out of $n=50$ are uncertain, which means the statement may be true or not. Only $4(8 \%)$ participants out of $n=50$ "disagree", and $8(16 \%)$ participants out of $n=50$ "strongly disagree". The findings show that $23(46 \%)$ participants out of $n=50$, representing the majority "strongly agree" or "agree" with the statement. This means that game-based teaching enhances the critical thinking skills of students.

Table18. Responses to the statement: The use of games improves my team work skills.

\begin{tabular}{|c|c|c|c|}
\hline & Frequency & Percent & Valid Percent \\
\hline Strongly agree & 16 & 32.0 & 32.0 \\
\hline Agree & 28 & 56.0 & 56.0 \\
\hline Uncertain & 2 & 4.0 & 4.0 \\
\hline Disagree & 3 & 6.0 & 6.0 \\
\hline Strongly disagree & 1 & 2.0 & 2.0 \\
\hline Total & 50 & 100.0 & 100.0 \\
\hline
\end{tabular}

The table above has to do with the statement "the use of games improves my team work skills". A total of $16(32 \%)$ participants out of $n=50$ "strongly agree" with the statement, and $28(56 \%)$ participants out of $n=50$ choose the "agree" option while only participants are 
uncertain. Only $3(6 \%)$ participants out of $n=50$ "disagree", and just one participant "strongly disagree" with the statement. According to the findings, it has been found that $44(88 \%)$ participants out of $n=50$, representing the majority of the whole sample "strongly agree" or "agree" with the statement. This reveals that games improve the team work skills of students.

\subsection{The effect of using games on the attitudes of English foreign language learners} towards each other, the language, and the teacher.

Table 19.Responses of the statement: I develop positive attitudes towards learning English as a foreign language when playing games.

\begin{tabular}{|c|c|c|c|}
\hline & Frequency & Percent & Valid Percent \\
\hline Strongly agree & 23 & 46.0 & 46.0 \\
\hline Agree & 20 & 40.0 & 40.0 \\
\hline Uncertain & 7 & 14.0 & 14.0 \\
\hline Disagree & 0 & 0.0 & 0.0 \\
\hline Strongly disagree & 0 & 0.0 & 0.0 \\
\hline Total & 50 & 100.0 & 100.0 \\
\hline
\end{tabular}

The table above is about the statement "I develop positive attitudes towards learning English as a foreign language when playing games". A total of $20(46 \%)$ participants out of $\mathrm{n}=50$ opt for the "strongly agree" option and $20(40 \%)$ participants out of $n=50$ select the "agree" option while 7 (14) participants out of $n=50$ are uncertain. However, no participants choose the "disagree" or the "strongly disagree" options. The findings show that $43(86 \%)$ participants out of $n=50$, representing the majority of the whole sample "strongly agree" or "agree" with the statement. This indicates that the integration of games in the classroom makes students develop positive attitudes towards learning English as a foreign language.

Table 20.Responses of the statement: I develop positive attitudes towards the teacher while playing games.

\begin{tabular}{|c|c|c|c|}
\hline & Frequency & Percent & Valid Percent \\
\hline Strongly agree & 27 & 54.0 & 54.0 \\
\hline Agree & 19 & 38.0 & 38.0 \\
\hline Uncertain & 0 & 0.0 & 0.0 \\
\hline Disagree & 0 & 0.0 & 0.0 \\
\hline Strongly disagree & 4 & 8.0 & 8.0 \\
\hline Total & 50 & 100.0 & 100.0 \\
\hline
\end{tabular}

The table above has to do with "I develop positive attitudes towards the teacher while playing games". A total of $27(54 \%)$ participants out of $n=50$ "strongly agree" with the statement, and $19(38 \%)$ participants out of $n=50$ "agree" with the statement while no participants are uncertain. Moreover, no participant "disagree" with the statement, and only 4 $(8 \%)$ participants out of $n=50$ choose the "strongly disagree" option. It has been found that 46 (92\%) participants, representing the majority of the whole sample "strongly agree" or "agree" with the statement. This shows that when games are used in the classroom, the students develop positive attitudes towards their teachers. 
Table 21. Responses to the statement: I develop positive attitudes towards my classmates when playing games in the classroom.

\begin{tabular}{|c|c|c|c|}
\hline & Frequency & Percent & Valid Percent \\
\hline Strongly agree & 23 & 46.0 & 46.0 \\
\hline Agree & 22 & 44.0 & 44.0 \\
\hline Uncertain & 0 & 0.0 & 0.0 \\
\hline Disagree & 3 & 6.0 & 6.0 \\
\hline Strongly disagree & 2 & 4.0 & 4.0 \\
\hline Total & 50 & 100.0 & 100.0 \\
\hline
\end{tabular}

The table above is about the statement "I develop positive attitudes towards my classmates when playing games in the classroom". A total of $23(46 \%)$ participants out of $n=50$ "strongly agree" with the statement, and 22 (44\%) participants "agree" with it while no participant is uncertain. Only $3(6 \%)$ participants out of $n=50$ "disagree" with the statement, and only $2(4 \%)$ participants out of $n=50$ "strongly disagree" with it. The results demonstrate that $45(90 \%)$ participants out of $n=50$, representing the majority of the whole sample choose the "strongly agree" or the "agree" option. This indicates that the use of games in the classroom makes students develop positive attitudes towards their classmates.

Table 22. Responses to the statement: I become motivated when playing games in the classroom

\begin{tabular}{|c|c|c|c|}
\hline & Frequency & Percent & Valid Percent \\
\hline Strongly agree & 21 & 42.0 & 42.0 \\
\hline Agree & 28 & 56.0 & 56.0 \\
\hline Uncertain & 0 & 0.0 & 0.0 \\
\hline Disagree & 1 & 2.0 & 2.0 \\
\hline Strongly disagree & 0 & 0.0 & 0.0 \\
\hline Total & 50 & 100.0 & 100.0 \\
\hline
\end{tabular}

The table above is about the statement "I become motivated when playing games in the classroom". A total of 21 (42\%) participants out of $n=50$ opt for the "strongly agree" option, and $28(56 \%)$ participants out of $n=50$ "agree" with the statement while no one is uncertain. Only 1 participant "disagrees" with the statement, and no participants "strongly disagree" with it. The results show that $49(83 \%)$ participants out of $n=50$, representing the majority of the whole sample choose the "strongly agree" or the "agree" option. This reveals that playing games motivate the students.

Table 23. Responses of the statement: Games decrease my level of anxiety and stress 


\begin{tabular}{|c|c|c|c|}
\hline & Frequency & Percent & Valid Percent \\
\hline Strongly agree & 5 & 10.0 & 10.0 \\
\hline Agree & 32 & 64.0 & 64.0 \\
\hline Uncertain & 4 & 8.0 & 8.0 \\
\hline Disagree & 2 & 4.0 & 4.0 \\
\hline Strongly disagree & 7 & 14.0 & 14.0 \\
\hline Total & 50 & 100.0 & 100.0 \\
\hline
\end{tabular}

The table above deals with the statement "games decrease my level of anxiety and stress". A total of $5(10 \%)$ participants out of $n=50$ "strongly agree" with the statement, and 32 $(64 \%)$ "agree" with the statement while only $4(8 \%)$ participants out of $n=50$ are uncertain. Only 2 participants "disagree" with the statement, and 7 (14\%) participants out of $=50$ "strongly disagree" with it. The findings show that $37(74 \%)$ participants out of $n=50$, representing the majority of the whole sample "strongly agree" or "agree" with the statement. This means that games do decrease the level of anxiety and stress of students.

Table 24. Responses to the statement: I do not feel shy when asking my classmates or my teacher for help when I don't understand the rules of a game.

\begin{tabular}{|c|c|c|c|}
\hline & Frequency & Percent & Valid Percent \\
\hline Strongly agree & 18 & 36.0 & 36.0 \\
\hline Agree & 23 & 46.0 & 46.0 \\
\hline Uncertain & 4 & 8.0 & 8.0 \\
\hline Disagree & 5 & 10.0 & 10.0 \\
\hline Strongly disagree & 0 & 0.0 & 0.0 \\
\hline Total & 50 & 100.0 & 100.0 \\
\hline
\end{tabular}

The table above has to do with the statement "I do not feel shy when asking my classmates or my teacher for help when I don't understand the rules of a game". As the results show, $18(36 \%)$ participants out of $n=50$ "strongly agree" with the statement, and $23(46 \%)$ participants out of 50 "agree" with it while only $4(8 \%)$ participants out of $n=50$ are uncertain. Only $5(10 \%)$ participants out of $n=50$ "disagree" with the statement, but no participants "strongly disagree" with it. It has been found that the $41(82 \%)$ participants out of $=50$, representing the majority of the whole sample choose either the "strongly agree" or the "agree" option in comparison with the other options. This indicates that the students do not feel shy to ask their teachers or classmates for help if they do not understand the rules of a game.

\section{DISCUSSIONS}

The study attempts to investigate the impact of the implementation of games in the classroom on the learning of English as a foreign language. With respect to the adopted method for the study, a quantitative methodology is used to answer the research questions. The results indicate that the integration of games in the classroom has many positive impacts on the teaching of English as a foreign language. Concerning the first research question " to what extent students learn English as a foreign language through games-based teaching", the results show that the use of games in the classroom to teach English as a foreign language boosts the 
four language learning skills of students and improves their vocabulary repertoire. This indicates that the use of games in the classroom helps students to progress in learning English as a foreign language. It is also important to point out the fact that though the age of participants isbetween 18 years old to 50 years old, they enjoy the use of games in the classroom and benefit from it. This indicates that the use of games in the classroom is useful in teaching English foreign language students, who are adults or seniors.

For the second research question "does games based teaching help learners to practice their English?", it has been found that the use of games in the classroom encourages students to use their English. That is to say, games-based teaching promotes participation in the classroom without the fear of making mistakes, being embarrassed etc.... For the third research question "does game-based teaching create an appropriate environment for students to learn English as a foreign language"? it has been found that the use of games in the classroom creates a stress-free environment for students to learn the language. In other words, the use of games makes students develop positive attitudes towards themselves, the language learning, and the teacher. With respect to the last question " to what extent are students satisfied with gamesbased teaching?", it has been found that students develop their critical thinking skills, problemsolving skills, and teamwork skills. In this regard, the integration of games in the classroom promotes and facilitates the learning of many crucial skills required in the academic carrier of students in specific and their daily lives in general. This is because many games involve the use of the previous skills mentioned. The results of the present study build on the existing studies conducted on the implementation of games in the classroom in teaching English. The results are in support of the previous researches which found that the integration of games in the classroom has many great, positive impacts on the learning of English as a foreign language as shown in the literature review. The study provides a new insight into the positive impacts of games-based teaching on the attitudes of foreign English language learners in the sense that the attitudes of learners can either lead to good language learning or block the process of learning a language.

With regard to the integration of games in teaching English as a foreign language, some recommendations can be generated. First and foremost, teachers should be aware of the positive impacts of using games in the classroom on the learning of English as a foreign language, specifically the attitudes of learners because they play a key role in the language learning process. Second, the teachers should be aware of how to use games in the classroom, which games to use, and why they should use them. As explained in the literature review, many challenges can face the teachers when using games, such as the miss management of the classroom, the personality of learners, their cultural background, etc... . Third, the teachers should use games to improve the four language learning skills of students that are demanding at the university. For example, the results show that using communicate games improve the speaking skills of students which indicate that students are also able to improve their public speaking skills that are required in the university and in the carrier of students . Last but not least, teachers should be aware that games can improve the critical thinking skills of students, their problem solving skills, and their team work skills. To this end, teachers should implement games for the sake of improving these demanding, vital skills.

\section{CONCLUSION}

The present study aims to investigate the impact of using games in the classroom on the teaching of English as a foreign language. Based on the findings and the discussions, it can be concluded that the implementation of games hasmany positive impacts on the learning of 
English as a foreign language. The results of the study have demonstrated that the English foreign language students benefit a lot from the use of games in the classroom due to the nature of this teaching technique that is characterized by fun and play. These results indicate clearly the importance of games-based teaching and its positive effects on the attitudes of English foreign language learners as demonstrated in the literature review and the results. To this end, games should be used in the Moroccan, educational system, be it the primary school, the secondary school, the college or the university in order to teach English as a foreign language.

\section{REFERENCES}

Blanka F, K.(2015). Procedia - Social and Behavioral Sciences 191: Games in the Teaching of English. (pp1157 - 1160)

Blanka,F. K. (2015). Games in the Teaching of English: Procedia - Social and Behavioral Sciences 191 ( 2015 ) $1157-1160$

Cohen, K. J., \&Rhenman, E. (1961). The role of management games in education and research. Management Science, 7(2), 131-166.

Connolly, T \& Stansfield, M.(2006). Using Games-Based eLearning Technologies in Overcoming Difficulties in Teaching Information Systems. Journal of Information Technology Education. Volume 5.

Deguang, Z.(2012). Using Games to Improve Students' Communicative Ability. Journal of Language Teaching and Research, Vol. 3, No. 4, pp. 801-805

Dorn, D. S. (1989). Simulation games: One more tool on the pedagogical shelf. Teaching Sociology, 17(1), 1-18.

Franklin, S., Peat, M., \& Lewis, A. (2003). Nontraditional interventions to stimulate discussion: the use of games and puzzles. Journal of Biological Education, 37, 79-84

Garris, R., Ahlers, R., \& Driskell, J. E. (2002). Games, motivation, and learning: A research and practice model. Simulation \& Gaming, 33(3), 441-467.

Gozcu, E. \&Caganaga, C. , K.(2016). The importance of using games in EFL classrooms. Cypriot Journal of Education Science.11 (3), 126-135.

Gozcu, E. \&Caganaga, C., K. (2016). The importance of using games in EFL classrooms. Cypriot Journal ofEducational Science. 11(3), 126-135

Hadfield, J. (1990). A Collection of Games and Activities for Low to Mid-Intermediate students of English. Intermediate Communication Games. Hong Kong: Thomus and Nelson and Nelson and Sons Ltd.

Hadfield, J. (1998). Elementary vocabulary games. Harlow: Pearson Education Limited

Haldfield, J. (1999). A collection of games and activities for low to mid -intermediate students of English:intermediate communication games", (Hongkong :Thomus and Nelson and Nelson and Sons).

Hansen, M, (1994), The use of games for vocabulary presentation and revision. „Forum'Vol 36 No 1, January,March 1998 ,( London: Newbury House Publisher)

Hays, R. T., \& Singer, M. J. (1989). Simulation fidelity in training system design: Bridging the gap between reality and training. New York: Springer-Verlag.

Hays, R. T., \& Singer, M. J. (1989). Simulation fidelity in training system design: Bridging the gap between reality and training. New York: Springer-Verlag.

Jacobs, G. (n.d. b). Using games in language teaching.

Jassim, L, Land., \&Dzakiria, H (2019). A Literature Review on the Impact of Games on Learning English Vocabulary to Children. International Journal of Language and Literary Studies. Volume 1, Issue 1.

Karen A. Milczynski.(2011). Literature Review: Effectiveness of Gaming in the Classroom. 
Krashen, S. (2011). The Compelling (not just interesting) Input Hypothesis. The English Connection. A Publication of KOTESOL. 15 (3).

Krashen,S .(2013). Second Language Acquisition. Theory Application and Some Conjectures: The Affective Filter Hypothesis. Publisher: Cambridge University Press.

Leemkvil, H., de Jong, T., \&Ootes, S. (2000). Review of educational use of games and simulations (Knowledge management Interactive Training System Project No. IST1999- 13078).

MacKenty, B. (2006). All Play and No Work. School Library Journal, 52, 46-48.

Mubaslat, M. M. (2012). The Effect of Using Educational Games on the Students' Achievement in English Language for the Primary Stage. Online Submission.

Nalasco,A..( 1991). Songs Games for Children. Oxford, Macmillan Publisher Limited, p.76.

Ratna Sari, D., Ummi, K,.\& Ari Armadi. (2016). Using Communicative Games in Improving Students' Speaking Skills. Using Communicative Games in Improving Students' Speaking Skills. Publisher: Canadian Center of Science and Education. doi: 10.5539/elt.v10n1p63

Robert T. Hays.(2005). The Effectiveness of Instructional Games: A Literature Review And Discussion Naval Air Warfare Center Training Systems Division Orlando, Fl 328263275. ( P4-63)

Robert T. Hays.(2005). The Effectiveness of Instructional Games: A Literature Review And Discussion Naval Air Warfare Center Training Systems Division Orlando, Fl 328263275. ( P4-63)

Rooyackers, P. (2002). 101 language games for children: Fun and learning with words, stories and poems. USA, CA: Hunter House Inc.

Schultz, M. and A. Fisher. (1988). Interacting in the Language Classroom. Games for All Reasons. Massachusetts: Addison-Wesley Publishing Company.

Vijayalakshmi, M.(2014). Teaching Grammar Through Games. An International Multidisciplinary Journal. Volume 3. Issue 1.

Wang, X., \& Dostál, Jiř́i. (2018). USING Digital Educational Games For English Foreign Language Learning. 10.21125/edulearn.2018.0060.

Wismath, S., Orr, D. \& MacKay, B. (2015). Threshold concepts in the development of problem-solving skills. Teaching and Learning Inquiry: The International Society for the Scholarship of Teaching and Learning, 3(1), 63-73.

Wright, A., D. Betteridge, M. Buckby. (2006). Games for Language Learning (3rd edn.). Cambridge: Cambridge University Press 